\title{
Dioscorea dumetorum Pax as an Alternative Starch Source for Industrial Applications
}

\author{
Oluwasina O. $\mathrm{O}^{*}$, Wahab O. J ${ }^{1}$, Umunna Q. C ${ }^{1}$, Nwosa, O. C ${ }^{1}$, \\ ${ }^{1}$ (Department of Chemistry, Federal University of Technology, Akure, Ondo State, Nigeria) \\ *Corresponding author: oooluwasina @ futa.edu.ng
}

\begin{abstract}
The increasing use of starch as alternative raw material for petroleum based chemical has been creating pressure on the food chain as most starches are obtained from food sources like cassava. There is therefore need to secure alternative starch source from non-edible underutilized plant materials. This study seeks evaluate the suitability of starch extracted from wild bitter yam (DioscoreadumetorumPax) for industrial applications, by comparing its physicochemical properties with that of cassava starch. Results revealed that bitter yam starch has relatively better physicochemical parameters. It possesses a desirable lower moisture content of $10.69 \pm 0.09 \%$ against $12.38 \pm 0.03 \%$ of cassava starch. Amylose/amylopectin percentage ratio was $75.79 \pm 1 / 24.21 \pm 1.00$ and $78.40 \pm 1.77 / 21.60 \pm 1.77$ for bitter yam and cassava starch respectively. Furthermore, the higher swelling capacities, moisture sorption capacity and gelatinization temperature recorded for bitter yam starch are pointer to its potential in certain food-related applications; paints, paper and adhesives production; and as pharmaceutical excipients. The ash content and $\mathrm{pH}$ was found to be $0.437 \pm 0.15 \%$ and $6.9 \pm 0.2$ for bitter yam starch while cassava starch recorded $0.418 \pm 0.17 \%$ and $8 \pm 0.4$. All the obtained values are within the recommended official specification for starch and suggest that bitter yam starch could be a promising source of cheap starch for industrial uses.
\end{abstract}

Keywords: Bitter yam, Cassava, starch, physicochemical properties, and industrial applications

\section{Introduction}

The adverse environmental pollution and human related health effect caused by petroleum based synthetic polymer is a major concern to scientists worldwide. This has necessitated the need for alternate raw material which could be biodegradable with little or no-environmental or human healthy effect to replace the existing petroleum based synthetic raw materials. Starch has been found to be one of the choicest biopolymer for such needs. Starch from yam, cassava, potato, cereals and other edible tubers have been extracted and used for various industrial purposes [1-3]

The versatility of the application of starch cannot be over-emphasized. It has been recognized to be one of the most widely used biomaterial [4]. This is so, not only because it is low-cost and availability, but also because of its relative ease of changing its physicochemical properties through physical, chemical and enzymatic treatment to suit diverse specifications $[4,5]$.

The global starch production has rose dramatically from 38 million metric tonnes in early 1990s to the whooping record of 68 million MT in 2009 and 73 million MT in 2011, with healthy increase in subsequent years [6,7]. Yet, the demand for starch remains insatiable. Aside its food related usefulness, it is also used for producing match-head binder in explosive industries; for sizing operations in paper industry; asbestos, paint fillers and gypsum board binder in the construction industry; fabric finishing in the textile industry; dusting powder / dusting agent, pill coating, tablet binder / dispersing agent in the cosmetic and pharmaceutical industry; mining and metal industries are not left out $[4,6]$.

Cassava, ManihotesculentaCrantz, is a root crop actively cultivated across the tropical and sub-tropical areas of the world and has transformed over the decades from a state of subsistent appreciation to become a leading commercial crop, of immense relevance to the processing industries and heavily contributing to the national income of several developing countries [8].It is one of the top three sources of food in the tropics and contributes significantly to the global starch production [9]. It would not be an exaggeration to say that cassava starch has been extensively utilized if not over- patronized for starch-related purposes, yet the world need for starch remain insatiable [3, 5-13]. Hence, the need for an appropriate, and preferably less exploited, alternative source of starch with suitable physicochemical properties. Worthy of consideration in this category is trifoliate yam. 
DioscoreadumetorumPax belongs to the genus Dioscorea and family Dioscoreaceae. The plant has both the wild and cultivated species. The wild one could be found in bushes, uncultivated lands and jungles, in most part of the tropic Africa, sometimes used for arrow poison [14], while its cultivated species are among the staple foods of the tropics [15].The existence of both the wild and cultivate species of this tuber made some local people in Nigeria considered Dioscoreadumetorum as food taboo, and could be considered as endangered species. The wild species known as "Esuru-Igbo or bitter yam" is highly toxic to humans if not well cooked, it has been used for animal poisoning in some part of Africa when mixed with Bart [16,17]. Owing to its bitter taste as the name implies, the wild forms are rarely eaten except during famine [18]. Furthermore, aside certain medicinal uses and potential application in baking, bitter yam has no established industrial application at present $[15,18-20]$.

The use of starch from edible tubers has adversely affected food chain most especially in some tropical and subtropical countries where those tubers are their essential dietary nutrient and staple foods [21-23]. Although, there are other non-edible tubers that could be used for industrial purposes, the non-availability of adequate information on their properties has limited their usefulness. Thus, the aim of this study is to unravel the physicochemical properties of starch obtained from wild DioscoreadumetorumPax, in comparison to that of Cassava, ManihotesculentaCrantz, in order to provide information for its potential use as substitute of cassava starch for industrial applications.

\subsection{Samples Collection}

\section{Materials and Methods}

The Cassava tuber, ManihotesculentaCrantz, was gotten from Agbani farm plantation, Gbonyin local government area, in Arunpale, Ekiti State, Nigeria. While the trifoliate Yam tuber, Dioscoreadumentorum, was obtained from Alfa Jimoh's compound in Ado-Ekiti, Ekiti State, Nigeria. NaOH, xylene, glacial acetic acid, ethanol and iodine are Sigma Aldrich product.

\subsection{Extraction of Starch}

The extraction method was based on reported work [24]. In brief, the harvested tubers were properly washed with water to remove soil particles before being peeled, sliced and grinded in a milling machine with small volumes of water. The homogenates were mixed with distilled water [homogenate: water (1:5)] and then sieved. The resultant slurry was allowed to settle for eight hours before the supernatant was decanted. The sediment was washed several times by re-suspending in distilled water and precipitating. The starch mash was dried at $50{ }^{\circ} \mathrm{C}$ to constant. The starch was then sieve and sieve size of $249-212 \mu \mathrm{m}$ samples was used. The sieved material was packed in air tight plastic and stored at room temperature for further use.

\subsection{Determination of Physicochemical Properties of Starch \\ 2.3.1 Moisture Content}

The method of [25] was used. About $2 \mathrm{~g}$ of starch was weighed and transferred into previously dried and weighed crucible. The crucibles with starch samples were placed in a thermostatically controlled oven and heated at $105^{\circ} \mathrm{C}$ for $3 \mathrm{~h}$ to a constant weight. The crucibles were removed and cooled in a desiccator and reweighed. The percentage loss on drying was calculated. This procedure was repeated in triplicate.

$$
\% \text { Moisture }=\frac{\mathrm{W} 1-\mathrm{W} 2}{\mathrm{~W} 1} \times 100
$$

$$
\begin{aligned}
& \text { Where; } \\
& \mathrm{W}_{1}=\text { initial weight of the sample }(\mathrm{g}) \\
& \mathrm{W}_{2}=\text { weight of the oven-dried sample }(\mathrm{g})
\end{aligned}
$$

\subsection{2 pH}

The $\mathrm{pH}$ was determined by adding about five grams of yam flour/starch into $10 \mathrm{~mL}$ of distilled water in a beaker, stirred to obtain slurry and then leave to settle. Using a Blue Line digital pH meter (Schott $\mathrm{CG} 8842 / 14 \mathrm{pH})$, the $\mathrm{pH}$ of the slurry was measured. The determination was done in triplicate and the mean value of the sample was considered as the $\mathrm{pH}$ of the starch.

\subsubsection{Ash Content}

One gram $\left(\mathrm{W}_{0}\right)$ of starch was transferred into a porcelain crucible which had previously been ignited, cooled and weighed. The muffle furnace was preheated to $550{ }^{\circ} \mathrm{C}$ for 2 hours, after which the crucibles and its content were placed into the muffle furnace for 3 hours. The crucibles were removed, cooled in a desiccator and 
weighed with its contents $\left(\mathrm{W}_{2}\right)$. The total ash content was calculated and expressed as a percentage. This analysis was carried out in duplicate [27].

$$
\begin{aligned}
& \% \text { Ash content }=\frac{\mathrm{W} 2-\mathrm{W} 1}{\mathrm{Wo}} \times 100 \\
& \text { Where; } \\
& \mathrm{W}_{2}=\text { weight of crucible }+ \text { sample after ashing. } \\
& \mathrm{W}_{1}=\text { weight of crucible }+ \text { sample. } \\
& \mathrm{W}_{\mathrm{o}}=\text { weight of sample. }
\end{aligned}
$$

\subsubsection{Moisture Sorption Capacity}

About two grams (2g) of the individual starch powders (W) were weighed and put into a tarred petri dish. The samples were then placed in a desiccator containing distilled water at room temperature and the weight gained by the exposed samples at the end of a five-day period $(\mathrm{Wg})$ was recorded [27]. The amount of water absorbed (Wa) was calculated from the weight differences and expressed in percentage as

$$
\% \mathrm{Wa}=\{\mathrm{Wg}-\mathrm{W}\} \times 100
$$

Where:

$\% \mathrm{Wa}$ is the percentage amount of water calculated,

$\mathrm{Wg}$ is the weight of the sample after five-days,

$\mathrm{W}$ is the initial weight of the sample.

\subsubsection{Bulk and Tapped Density}

Bulk and tapped densities were determined by using $15 \mathrm{~g}$ of the sample (Wp) of the starch powder. This was gently poured through a short stemmed glass funnel into a dry $100 \mathrm{~mL}$ graduated measuring cylinder. The volume occupied by the sample without tapping was noted as Vp. The powder was tapped on a wooden surface at height of 7 inches until no further change in volume was observed. This volume (VpT) was taken as the tapped volume [25]. The densities were determined in triplicate.

The bulk $\left(\mathrm{B}_{\mathrm{d}}\right)$ and the tapped densities $\left(\mathrm{T}_{\mathrm{d}}\right)$ were calculated as follows

$\mathrm{B}_{\mathrm{d}}=\frac{W p}{V \mathrm{p}} \times 100$

$\mathrm{T}_{\mathrm{d}}=\frac{W p}{\mathrm{VpT}} \times 100$

Where;

Wp is the weight of the sample used,

$\mathrm{Vp}$ is the volume of the sample without tapping,

$\mathrm{VpT}$ is the volume of the sample after tapping.

\subsubsection{True Density}

The method found in [26] was used. The specific gravity bottle method was adopted, and xylene was used as displacement fluid. The bottle was cleaned and filed with xylene; all spilled over liquid (xylene) was wiped off with an absorbent cloth. The weight of the bottle filled with xylene was noted as "a", the bottle was emptied and cleaned. About $5 \mathrm{~g}$ of starch was weighed into the specific gravity bottle. The weight of the starch powder was noted as $\mathrm{W}$. The specific gravity bottle containing the starch was almost filled with xylene, stirred with glass rod and allowed to stand for $10 \mathrm{~min}$ for air bubbles to be released. The bottle was then carefully filled with xylene and the final weight of the bottle noted as "b". Starch true density was then calculated as:

$$
\mathrm{D}_{\mathrm{t}}=\frac{w}{\{(a+w)-b\}} \times S G
$$

Where;

$\mathrm{W}=$ weight of the sample,

$\mathrm{SG}=$ specific gravity of the solvent $($ xylene $)=0.855$

$\mathrm{a}=$ weight of the bottle + solvent

$\mathrm{b}=$ weight of the bottle + solvent + sample.

\subsubsection{Compressibility Index (Carr's index \%) and Hausner ratio}

The compressibility index (Carr's index) and Hausner ratio of the powder are determined using the method of [28] from the following equations:

$$
\begin{aligned}
& \text { Carr's index } \%=\frac{\text { Tapped density -bulk density }}{\text { Tapped density }} \times 100 \\
& \text { Hausner ratio }=\frac{\text { Tapped density }}{\text { Bulk density }}
\end{aligned}
$$




\subsubsection{Hydration Capacity}

The method reported in [26] was adopted. One gram $(1 \mathrm{~g})$ of each of the starch powder $(\mathrm{Y})$ was placed in a tarred $20 \mathrm{~mL}$ centrifuge tube. The weight of the tube was noted; $10 \mathrm{~mL}$ of distilled water was added and shaken vigorously for $2 \mathrm{~min}$. It was then allowed to stand for 10 min during which it was mixed by inverting the tube three times at the end of 5 and $10 \mathrm{~min}$. The sample was centrifuged at $3000 \mathrm{rpm}$ for $10 \mathrm{~min}$. The aqueous supernatant was then carefully removed and the tube with the sediment was re-weighed (X). The hydration capacity was calculated as the ratio of the weight of the sediment to the initial weight of the dry powder, rated in percentage. This procedure was done in triplicate and the mean taken.

$$
\begin{aligned}
& \text { Hydration capacity }=\frac{X}{Y} \times 100 \% \\
& \text { Where; } \\
& X \text { is the weight of sediment, } \\
& \mathrm{Y} \text { is the weight of dry powder. }
\end{aligned}
$$

\subsubsection{Swelling Capacity}

The swelling capacity of the starch powder was determined by the method of [28]. The tapped volume occupied by $5 \mathrm{~g}$ of the powder, $\mathrm{Vx}$, was noted. The powder was then dispersed in $85 \mathrm{~mL}$ of distilled water and the volume made up to $100 \mathrm{~mL}$ with more distilled water. After $24 \mathrm{~h}$ of standing, the volume of the sediment, $\mathrm{Vv}$, was estimated and the swelling capacity was computed. This was done in triplicate.

$$
\begin{aligned}
& \text { Swelling capacity }=\frac{\text { Volume of sediment }}{\text { Tapped volume }} \\
& \% \text { swelling capacity }=\frac{\mathrm{Vv}_{\mathrm{v}}-\mathrm{V}_{\mathrm{x}}}{\mathrm{Vx}} \times 100
\end{aligned}
$$

Where;

$\mathrm{Vv}$ is volume of sediment after $24 \mathrm{~h}$,

$\mathrm{Vx}$ is the volume of sample after tapping.

\subsubsection{Gelatinization Temperature}

This was evaluated using the method in[29] $1 \mathrm{~g}$ of the starch sample was put in a $20 \mathrm{~mL}$ beaker and 10 $\mathrm{mL}$ of distilled water was added. The dispersion was heated on a hot plate. The gelatinization temperature was then read with a thermometer suspended in the starch slurry.

\subsubsection{Determination of Amylose and Amylopectin Content}

Amylose content was determined using the method stated in [26].Approximately, $0.1 \mathrm{~g}(100 \mathrm{mg})$ of the samples was weighed into a $100 \mathrm{~mL}$ volumetric flask and $1 \mathrm{~mL}$ of 99.7 to $100 \%(\mathrm{v} / \mathrm{v})$ ethanol and $9 \mathrm{~mL}$ of $1 \mathrm{~N}$ sodium hydroxide $(\mathrm{NaOH})$ was carefully added and the mouth of the flask was covered with foil and the content was mixed well. The samples were heated for $10 \mathrm{~min}$ in a boiling water bath to gelatinize the starch (the timing was started when boiling began). The samples were then removed from the water bath and allowed to cool very well. It was then filled up to the mark with distilled water and shaken well. About $5 \mathrm{~mL}$ of the mixture was then pipetted into another $100 \mathrm{~mL}$ volumetric flask. Acetic acid $(1 \mathrm{~N}, 1.0 \mathrm{~mL})$ and $2 \mathrm{~L}$ of iodine solution were added, and top to mark with distilled water. Absorbance (A) was then read using spectrophotometer at $620 \mathrm{~nm}$ wavelength. The blank contained $1 \mathrm{~mL}$ of ethanol, $9 \mathrm{~mL}$ of sodium hydroxide, and then boiled and top up to the mark with distilled water. $5 \mathrm{~mL}$ was then pipetted into a $100 \mathrm{~mL}$ volumetric flask. Approximately, $1 \mathrm{~mL}$ of $1 \mathrm{M}$ acetic acid and $2 \mathrm{~mL}$ of iodine solution were added and then filled up to the mark, this was used to standardize the spectrophotometer at $620 \mathrm{~nm}$. The experiment was performed in triplicate and amylose content was calculated as:

$$
\begin{aligned}
& \text { Amylose content }(\%)=61.20 \times(\mathrm{A}) \\
& \text { Where; } \\
& \mathrm{A}=\text { Absorbance value } \\
& \text { Amylopectin }(\%)=100-\text { Amylose content }
\end{aligned}
$$

\subsection{Moisture content}

\section{Results And Discussion}

The result of the moisture content is as shown in Fig. 1, bitter yam starch has a lower moisture content of $10.69 \%$ compared to $12.38 \%$ recorded for cassava starch. The recorded values are less than the official acceptable value of $14 \%$ [30]. From the result it could be inferred that bitter yam starch would not decay faster during storage, because moisture content aids decaying/ spoilage activity microbes on food substances. This means that bitter yam starch would be have a long self-life. The lower moisture content of the bitter yam starch, therefore promises less occurrence of caking; microorganism infestation, off-flavour; and unwanted odour. In addition, it would be appropriate for use in drug formulation as high moisture content interfere with active ingredient [26]. 


\subsection{Moisture sorption capacity}

The moisture sorption capacity obtained for bitter yam starch and cassava starch at room temperature are $28 \%$ and $27 \%$ respectively (Shown in Fig. 1). The high moisture capacity of the bitter yam could be attributed to its high amylose content $(24.21 \%)$ against the $21.60 \%$ of the cassava starch. This high moisture sorption could also be the cause of its high swelling capacity as compared with the cassava starch. This is because starch moisture sorption has a proportional relationship to its swelling capacity [29,31]. The stated moisture sorption capacity of the bitter yam starch qualifies it for existing food-related applications such as use in cakes, canned meats, confectionary cream, diet/light meat products, fillings, desserts and powder soups [32]. Same goes for use as pharmaceutical excipient [33]. However, use for biofilm or bioplastics formulation is an exception as the least moisture absorbing starch is needed to give bioplastics the best physical stability when stored under humid conditions [27], thus there would be need for modification of the starch to reduce moisture absorptivity.

\subsection{Swelling capacity}

There is direct proportionality between moisture sorption and swelling capacity [29.31], thus it is not surprising to record $65.60 \%$ swelling capacity for bitter yam starch while cassava yam had $24.41 \%$ (Fig. 1). The results obtained here are within the ranged of values reported by [34] on starches from several sources. Swelling capacity affects the use of starch in industrial applications. Starch with high swelling capacity would improve digestibility and could be used for the improvement of dietary properties of food products e. $g$ noodles and would be a good disintegrant for pharmaceutical products such as solid dosage drug [7,31]. Also, the low moisture content of the bitter yam starch is another advantage for it to be used for pharmaceutical purpose, because low moisture content preserves the drug active ingredient. Bitter yam starch could therefore be used in range of dietary application.

\subsection{Ash Content}

Ash content was found to be $0.44 \%$ and $0.42 \%$ (Fig. 1) for bitter yam starch and cassava starch respectively. The ash content of a substance is usually a measure of the present mineral. However, the higher value attributed to bitter yam starch could be due to residual impurities from post-harvest handling. This correlates with the claim that "low ash content of starch could be considered as an indication of clean processing" [29]. The values are well below the maximum of $0.60 \%$ standard set by the both the British Pharmacopeia and the USP -NF (United States Pharmacopeia and National Formulary), for starch intended for pharmaceutical applications [30].

\subsection{Amylose and amylopectin content}

The amylose content of $24.21 \%$ was obtained for the bitter yam starch and $21.60 \%$ for cassava starch. The values compare well with the range declared for parents and progenies starch of nine Ugandan cassava varieties [31]. The low amylose content cassava starch is an indication that is has higher crystallinity and low amorphous content as compared with bitter yam. Also, the low amylose content of the cassava starch could be a pointer that products from cassava starch would have lower degree of retrogradation tendencies, which is caused by aggregation of amylose [13, 35].Also, the film forming ability of amylose is excellent and this is an important characteristics of starch for industrial applications, because film formed by amylose are very strong, colorless, odorless and tasteless [36]. Although, most bioplastics are currently being made from cassava starch, the amylose content of bitter yam starch is very close to that of cassava and it could be a substitute. Also, bitter yam starch could be a good raw material for products that require high amylose content. Furthermore, the amount of amylose present in each starch influenced the low swelling capacity of cassava starch, as showed in Fig. 1. 


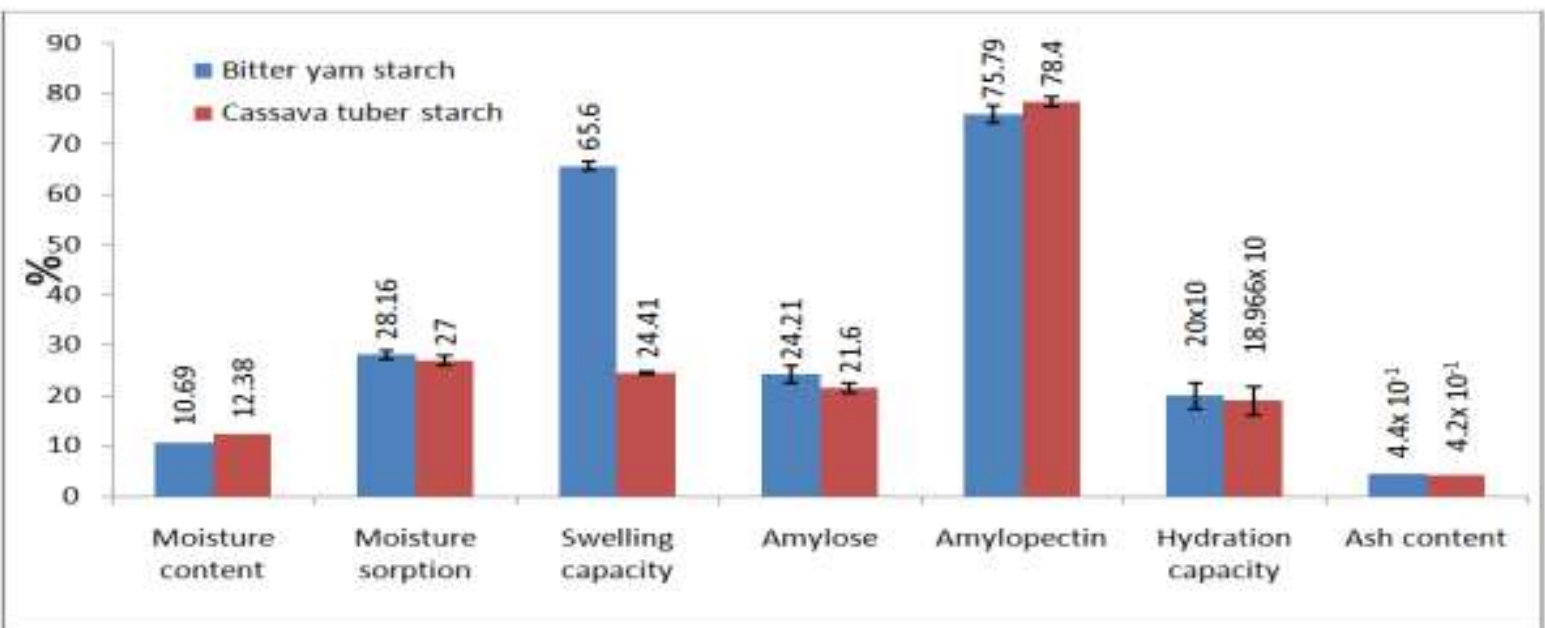

Figure 1: Moisture content, moisture sorption, swelling capacity, amylose, amylopectin, hydration capacity and ash content of cassava tuber starch and bitter yam starch

\subsection{Hydration capacity}

The hydration capacities are $200 \%$ and $189 \%$ (Fig. 1) for bitter yam starch and cassava starch respectively. This is in line with the performance observed for the moisture sorption and swelling capacity of the two starches as they are all a function of surface area available for absorption of water [26]. Hence, the implications of the hydration capacity on suitability for industrial applications are also similar to those mentioned for moisture sorption and swelling capacity.

\section{$3.7 \mathrm{pH}$}

The $\mathrm{pH}$ of the bitter yam starch and cassava starch are 7 and 8 respectively as shown in Fig. 2 are within the official acceptable $\mathrm{pH}$ value of 4-8 [30]. A pH of 4 or less would imply characteristic sour, aroma and taste due to fermentation, which is not appropriate for applications related to food and oral drugs.

\subsection{Carr's index and Hausner}

For pharmaceutical purposes the flow properties of the extracted starches would be of great important with respect to handling and compaction. Carr's index and Hausner ratio are used for indirect measurement of powder flowability [37]. A carr's index value below 16 is an indication of good flowability and above 20 is for not free flowing powdered material, while above 35 is an indication of cohesiveness [38]. When a Hausner ratio is greater than 1.25 the material is of poor flow characteristics. The obtained flowability results of the too starches showed that they have poor flow properties, having recorded Hausner ratio of 1.37 for bitter yam and 1.28 for cassava, while Carr's index of bitter yam was 26.00 and cassava 21.95 (Fig. 2). There would hence be need for addition of glidant before it could be used in solid dosage production processes.

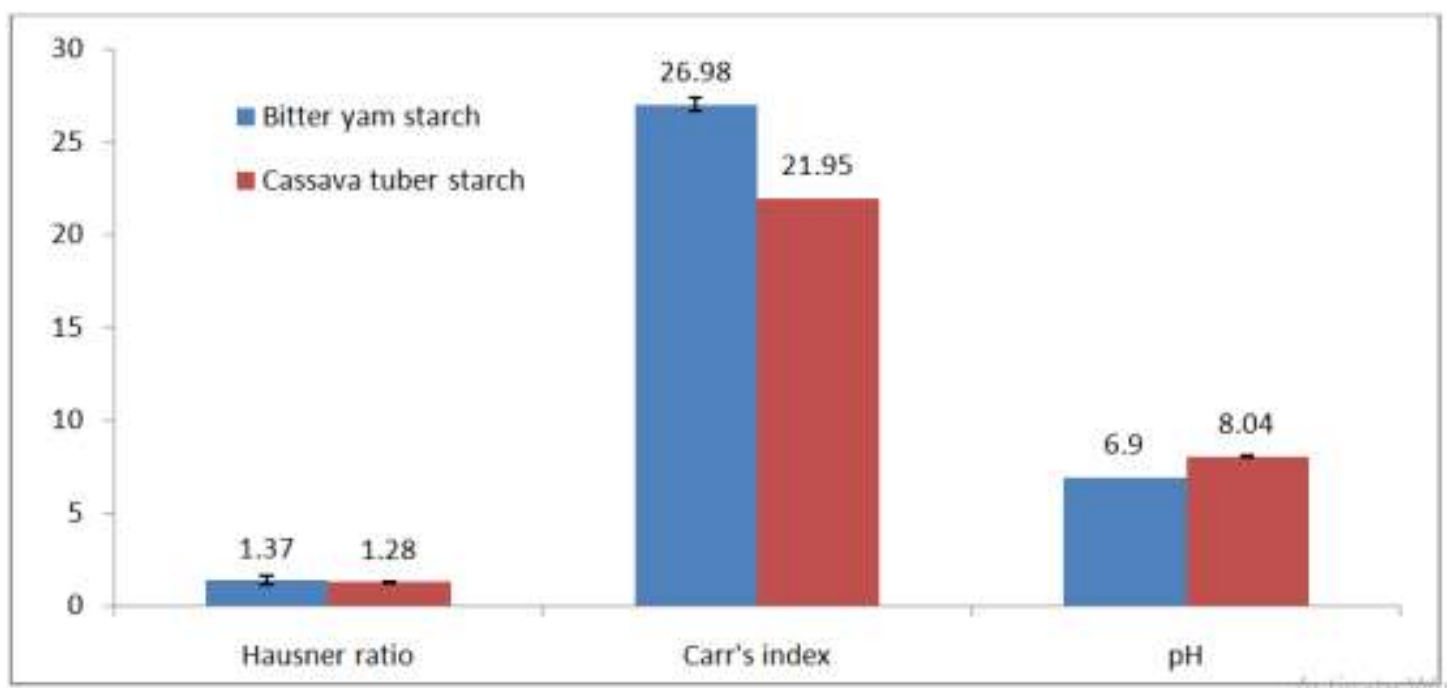

Figure 2: Hausner ratio, Carr's index and $\mathrm{pH}$ of cassava tuber starch and bitter yam starch 


\subsection{Bulk, Tapped and True Density}

Density of a powdered starch material could reflect its porosity. The results obtained (Fig 3) for bulk and tapped densities of cassava starch are 0.64 and 0.82 , while bitter yam starch had 0.46 and 0.63 . The results indicates that bitter yam starch was porous than the cassava starch. The low bulk and tapped densities of the bitter yam starch could be due to particle properties such as size, shape and surface roughness, because particle size and shape could lead to loose packing causing low bulk and tapped densities. The true density of 1.40 of bitter yam is higher than 1.28 of the cassava starch. True density can equal the theoretical density of the material and could be indicative of how close the material is to a crystalline state or the proportions of a binary mixture [39]. Also, the high true density of bitter yam starch would make it a good material for drug compressibility, because the better compressibility is obtained from materials with higher the true density.

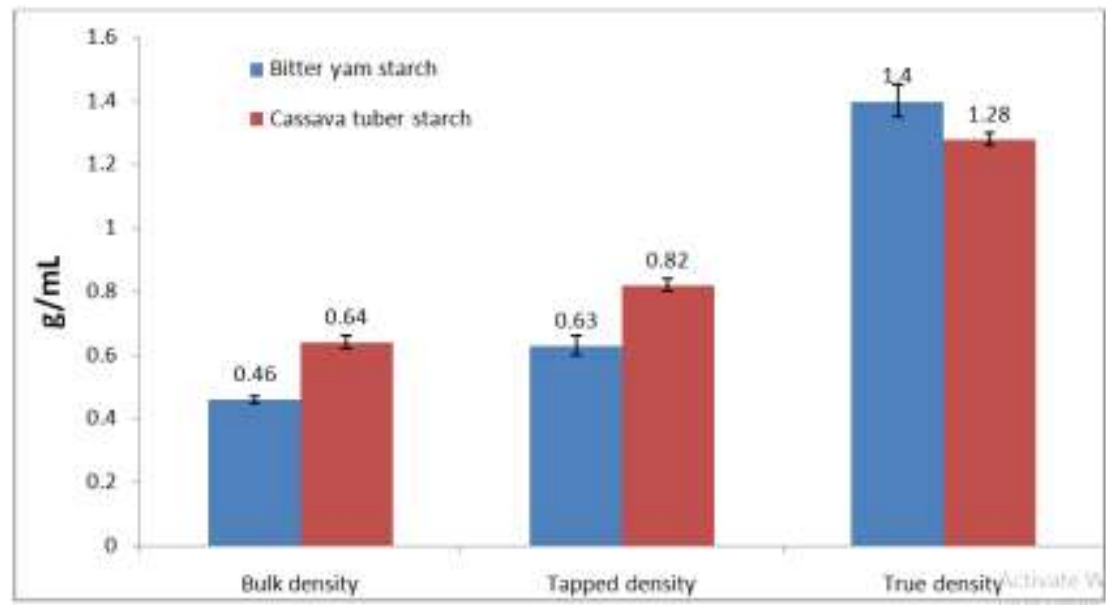

Figure 3: Bulk density, tapped density and true density of cassava tuber starch and bitter yam starch

\subsection{Gelatinization Temperature}

Gelatinization was observed at $81.33{ }^{\circ} \mathrm{C}$ and $75.66{ }^{\circ} \mathrm{C}$ for bitter yam starch and cassava starch respectively (Fig.4). Gelatinization results in the rupture of the starch grains, in other words, an irreversible loss of its particle structure [30]. Hence, high gelatinization temperature could be interpreted as good resistance to shear stress and this favours use for surface sizing and coatings in the paper, paint and adhesives industries [29]. High gelatinization temperature is usually accompanied with low viscosity, making the starch relevant in the production of canned foods where retrogradation and syneresis is detested. Furthermore, such starch are also especially demanded for use in extrusion/spheronization processes in the pharmaceutical industry [30].

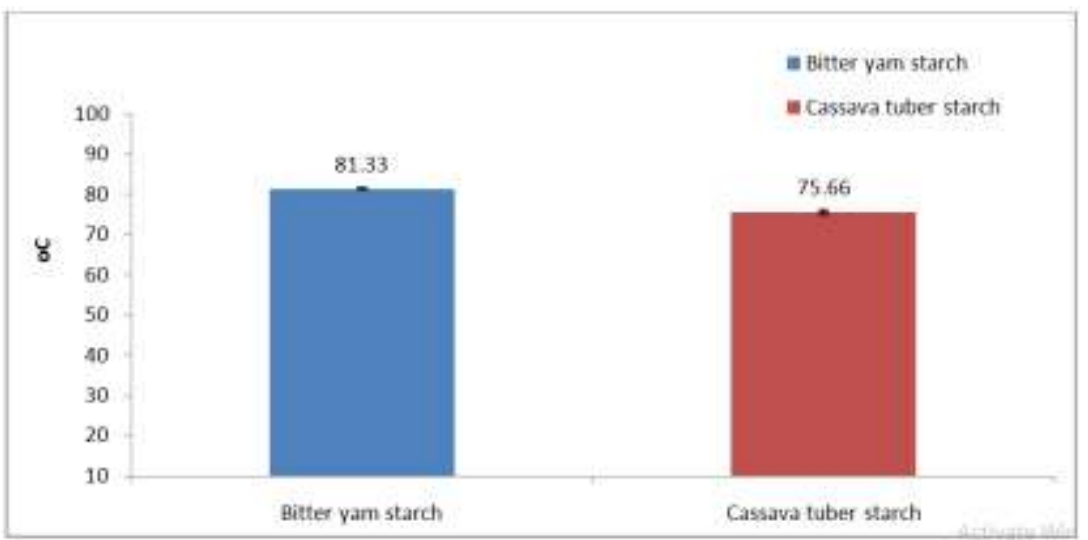

Figure 4: Gelatinization temperature of cassava tuber starch and bitter yam starch

\section{Conclusion}

Bitter yam starch (DioscoreadumetorumPax) starch has been isolated and its physicochemical properties studied. It compares impressively with starch from cassava (ManihotesculentaCrantz), exhibiting, in some cases, better characteristics important to industrial applications, especially those related to food, pharmaceutical, paper and biofilm production. Hence, it could be inferred that DioscoreadumetorumPax is a promising source of starch for diverse industrial applications, towards relieving the pressure on popular starch sources like cassava and meeting the ravenous starch demand of the modern world at low cost. 


\section{References}

[1]. T. Noda, T. Kimura, M. Otani, O. Ideta, T.Shimada, A. Saito, and I. Suda, Physicochemical properties of amylose-free starch from transgenic sweet potato. Carbohydrate Polymers. 49 (3), 2002, 253-260.

[2]. K. Kitahara, K. Hamasuna, K. Nozuma, M. Otani, T. Hamada, T. Shimada, K. Fujita, and T. Suganuma, Physicochemical properties of amylose-free and high-amylose starches from transgenic sweet potatoes modified by RNA interference. Carbohydrate. Polymers. 69(2), 2007, 233-240

[3]. S. Gomand, L. Lamberts, R. Visser, and J. Delcour, Physicochemical properties of potato and cassava starches and their mutants in relation to their structural properties. Food Hydrocolloids, 24 (4), 2010, 424-433

[4]. M. Omojola, Y. Akinkunmi, K. Olufunsho, H. Egharevba, E. Martins, Isolation and physico-chemical characterization of cola starch. African Journal of food, agriculture, nutrition and development. 10(7), 2010, $2884-900$.

[5]. S. Jobling, Improving starch for food and industrial applications. Current Opinion in Plant Biology. 7(2), 2004, 210 - 218.

[6]. C. F. Ostertag, World Production and Marketing of Starch, in D. Dufour, G. O'Brien and R. Best, Cassava flour and starch, 1 (Columbia: Centro Internacional de Agricultura Tropical, Cali, 1996) 105-112.

[7]. M. Omojola, Tacca Starch: a Review of Its Production, Physicochemical Properties, Modification and Industrial Uses. African Journal of Food Agriculture, Nutrition Development, 13(4), 2013,7972-7985.

[8]. P. Ozemoya, E. Ajisegiri, and P. Idah, Production of Adhesives from Cassava Starch. Leonardo Electronic Journal of Practices and Technologies, 10 (1), 2007, 93-98.

[9]. Srinivas, Industrial Demand for Cassava Starch in India. Starch - Stärke, 59(10), 2007, 477-481

[10]. G. Athira, A. Jyothi, Cassava starch-poly(vinyl alcohol) nanocomposites for the controlled delivery of curcumin in cancer prevention and treatment. Starch - Stärke, 67(5-6), 2015, 549-558.

[11]. S. Harnsoongnoen, and A. Siritaratiwat, Electrical and absorption properties of fresh cassava tubers and cassava starch. Journal Of Instrumentation, 10(09), 2015, P09004-P09004.

[12]. A. Olusola, O. Adebiyi, and K. Riyaad, Evaluation of new cassava varieties for adhesive properties. Starch - Stärke, 67(7-8), 2015, 561-566.

[13]. E. Rodriguez-Sandoval, J. Otálvaro-Arenas, and V. Hernandez, Bread quality of flours substituted with modified cassava starches. Starch - Stärke, 69(5-6), 2016, 246-253.

[14]. O. Fasaanu, M. Oziegbe, and O. Oyedapo, Investigations of activities of alkaloid of trifoliate yam (dioscoreadumetorum, (kunth) pax). Ife Journal of Science, 15 (2), 2013, 251-262.

[15]. R. Nimenibo-Uadia, Control of hyperlipidaemia ,hypercholesterolaemia and hyperketonaemia by aqueous extract of Dioscoreadumetorum tuber. Tropical Journal of Pharmaceutical Research, 2(1), 2003, 183-189.

[16]. J. Nwosu, N. Odimegwu, C. Ofoedu, J. Ibeabuchi, I. Olawuni, and K. Ikeli,Evaluation of the Proximate and Anti-nutritional Qualities of Ihu (dioscoreadumentorum). International Journal of Life Sciences. 3(3), 2014, 92-104.

[17]. U. Ukpabi, Molecular analysis of Dioscoreadumetorumin South-East Nigeria using random amplifiedpolymorphic DNA markers. American Journal ofMicrobiology and Biotechnology. 1 (2), 2014, 77-82.

[18]. M. McAnuff, W. Harding, F. Omoruyi, H. Jacobs, E. Morrison, and H. Aseota, Alteration in intestinal morphology of streptozotocin induced diabetic rats fed Jamaican bitter yam (Dioscoreapolygonoides) steroidal sapogenin extract. Nutrition Research 23(11), 2003, 1569- 1577

[19]. M. Sonibare, and R. Abegunde, In-vitro antimicrobial and antioxidant analysis of Dioscoreadumetorum (Kunth) Pax and Dioscoreahirtiflora (Linn.) and their bioactive metabolites from Nigeria. Journal of Applied Biosciences, 51, 2012, 3583-3590.

[20]. A. Egbuonu, D. Nzewi and, O. Egbuonu, Functional Properties of Bitter Yam Dioscoreadumetorum) as Influenced by Soaking Prior to Oven-drying. American Journal of Food Technology, 9(2), 2014, 97-103

[21]. M. Bhandari, T. Kasai, and J. Kawabata, Nutritional evaluation of wild edible yam (Dioscoreasp.) tubers of Nepal. Food Chemistry, $82(4), 2003,619-623$

[22]. A. Cogne, A. Marston, S. Mavi, K. Hostettmann, Study of two plants used in traditional medicine in Zimbabwe for skin problems and rheumatism: Dioscoreasylcaticaand Urgineaaltissima. Journal of Ethanopharmacology, 75(1), 2001, 51-3.

[23]. E. Okeoghene, E. John and O. Ose, Profitability Analysis of Yam Production in Ika South Local Government Area of Delta State, Nigeria.Journal of Biology, Agriculture and Healthcare. 3(2), 2013, 118-129

[24]. O. Oluwasina, Q. Umunna, S. Olusegun, O. Wahab,Physico-chemical propertiesof cassava starch and starch-keratin prepared biofilm. Songklanakerin Journal Science and Technology; (38)4, 2016, 349-355.

[25]. O. Olayemi, A. Oyi and T. Allagh, Comparative evaluation of maize, rice and wheat starch powders as pharmaceutical excipients. Nigerian Journal of Pharmaceutical Science, 7(1), 2008, 154-161.

[26]. J. Muazu, H. Musa, A. Isah, P. Bhatia, and G. Tom, Extraction and characterization of Kaffir Potato Starch : A potential source of pharmaceutical raw material, Journal of Natural Product and Plant Resources, 1(2), 2011, 41-49.

[27]. Ohwoavworhua, F.O., Kunle, O.O and Ofoefule, S.I. (2004). Extraction and Characterization of Microcrystalline cellulose derived from Luffa cylindrical plant. African Journal of Pharmaceutical Resources and Development, 1(1), 2004, 1 -6.

[28]. L. Pachuau, H. Lalhlenmawia, B. Mazumder, Characteristics and composition of Albiziaprocera (Roxb.) Benth gum. Industrial Crop and Products, 40, 2012, 90-95.

[29]. M. Iwuagwu and P. Okoli, The disintegrant properties of pregelatinized cassava and white yam starch. Pharmaceutical World Journal, 9, 1992, 49-53.

[30]. J. Akpa and K. Dagde, Modification of Cassava Starch for Industrial Uses. International Journal of Engineering and Technology. 2(6), 2012, 908-914.

[31]. C. R. Raymond, J. S. Paul, and E. Q. Marian, (2009). Handbook of Pharmaceutical Excipients (Pharmaceutical Press, London, 2009).

[32]. E. Nuwamanya, Y. Baguma, N. Emmambux, J. Taylor, and R. Patrick, Physicochemical and functional characteristics of cassava starch in Ugandan varieties and their progenies. Journal of Plant Breeding and Crop Science. 2(1), 2010, 001-011.

[33]. I. Demiate and V. Kotovicz, Cassava starch in the Brazilian food industry. Ciência E Tecnologia de Alimentos, 31(004204), 2011, 388-397.

[34]. K. Chowdary and V. Enturi, Preparation Characterization and Evaluation of Starch Citrate- A New Modified Starch as a Disintegrant in Tablet Formulations. International Journal of Pharmaceutical Research And Development 12 (2), 2011, 9-17.

[35]. M. Salwa, M. Abo-El-Fetoh; M. Hanan, M. Al-Sayed and M. Nessrien, Physiscochemical Properties of Starch Extracts from Different Sources and Their Application in Pudding and White Sauce. World Journal of Dairy and Food Sciences 5(2), 2010, 173182

[36]. T. Tukomane, P. Leerapongnun, S. Shobsngob, S. Varavinit, Preparation and Characterization of Annealed- Enzymatically Hydrolyzed Tapioca Starch and the Utilization in Tableting. Starch - Stärke 59(1), 2007, 33-45. 
[37]. C. Campos, L. Gerschenson, and S. Flores, Development of edible films and coatings with antimicrobial activity. Food and Bioprocess Technology, 4(6), 2011, 849-875.

[38]. O. Oluwasina, L. Lajide and B. Owolabi, Microcrystalline Cellulose from Plant Wastes through Sodium Hydroxide-AnthraquinoneEthanol Pulping. BioResources. 9 (4), 2014, 6166-6192.

[39]. N. Bhimte, and T. Pralhad, Evaluation of microcrystalline cellulose prepared from sisal fibers as a tablet excipient: A Technical note. AAPS Pharmaceutical Science andTechnology, 8 (1), 2006, 8-10.

[40]. M. Achor, Y. Oyeniyi, and A. Yahaya, Extraction and characterization of microcrystalline cellulose obtained from the back of the fruit of Lagerianasiceraria (water gourd). Journal of Applied Pharmaceutical Science. 4 (01), 2014, 057-060. 